\section{Facilitators and Barriers faced by Mobile Payment Fintechs in the Brazilian Context}

\author{
Gabriel Braido ${ }^{1}$ \\ gbraido@gmail.com| (D) 0000-0001-7640-080X \\ Amarolinda Klein ${ }^{1}$ \\ aczanela@unisinos.br|(1) 0000-0001-8585-9057 \\ Guilherme Papaleo ${ }^{1}$ \\ papaleo.guilherme@gmail.com|(1) 0000-0003-3571-8103
}

\begin{abstract}
Fintechs have created a new global financial reality, providing access to services that were previously provided only by banks. This article aims to identify facilitators and barriers faced by mobile payment fintechs for their entry and development in the Brazilian context. The research method was a single case study, whose unit of analysis was the mobile payment fintech sector in the Brazilian context, involving nine companies in this industry. As a result, we identified that several factors act as facilitators to the entry and development of fintechs, such as convenience and focus of their solutions, innovation in the use of technology, collaboration, and partnerships between fintechs. However, several barriers are faced in the emergence and development of these companies, such as regulatory issues, investment needs, difficulties in finding partners, and conflicts of interest with major players in the financial market. These results offer inputs to fintech entrepreneurs and suggest directions to regulators and public policymakers.
\end{abstract}

\section{KEYWORDS}

fintechs, entrepreneurship, mobile payments, facilitators and barriers

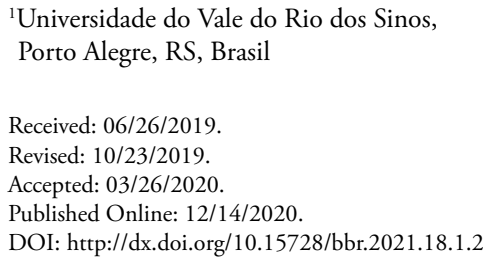




\section{INTRODUCTION}

The payment industry currently experiences the convergence of technologies for processing transactions, as well as several changes in consumer behavior that favor the adoption of new payment methods around the world (Gozman, Liebenau \& Mangan, 2018). Mobile payments (mobile payment or m-payment) involves payments through the use of a mobile device and wireless communication networks (Dahlberg, Gou \& Ondrus, 2015; Lee, Ryu \& Lee, 2019).

The use of mobile payments is one of the most promising innovations for financial inclusion due to the spread of smartphones and the ease of use of mobile technologies (Iman, 2018). This form of payment has been one of the main drivers of socio-economic development in emerging markets and is increasingly replacing traditional means of payment (Moon, 2017). In Brazil, the Brazilian Association of Credit Card and Services Companies (ABECS) indicates that mobile payments are already a reality in the country, with the entry of Apple Pay and Samsung Pay and estimates that, by 2030, banknotes and coins may be replaced by these new means of payments (The Revolution ..., 2018).

However, emerging technologies do not necessarily create economic value; they need to be leveraged and exploited by entrepreneurs (Steininger, 2019). Thus, several startups have emerged and offered financial services in an innovative, efficient, and less expensive way, based on digital technologies. They are called fintechs (Prado, 2016; Murshudli \& Loguinov, 2019). The term "fintech" represents the combination of the terms "financial" and "technology" (Prado, 2016). Fintechs have created a new global financial reality, providing access to services previously provided exclusively by banks (Gomber et al., 2018). These companies can break paradigms of the traditional financial system, which often inefficiently uses the available technological resources (Prado, 2016; Du, 2018).

Therefore, the technology, once considered a barrier of entry in the payment industry, is now seen as an entry factor, especially with the spread of mobile technologies. Thus, new players, such as fintechs, seek to compete for opportunities in the sector, while traditional financial institutions try to remain relevant and sustainable in this new business scenario (Leong et al., 2017; Dallagnol \& Verschoore Filho, 2018).

However, experts have pointed out several challenges to be faced in the Brazilian fintech market in the coming years, especially concerning the approaches that banks will create to deal with the growth of these companies (Conheça..., 2017). Among the issues to be analyzed, it is worth understanding the retailers' intention to adopt new payment technologies (Lee, Ryu \& Lee, 2019), the advantages of adopting several mobile payment platforms (Shaikh, Hanafizadeh $\&$ Karjaluoto, 2017), the relationship between innovation and information security (Arner et al., 2019; Murshudli \& Loguinov, 2019) and the emergence of new government regulations (Fenwick; Kaal; Vermeulen, 2018).

In this scenario, it is essential to analyze the development of fintechs, which can contribute to financial inclusion and offer innovative payment services, thus contributing to the local development. Startups are more susceptible to failure due to their initial vulnerability; they face many risks, have fewer resources and have little legitimacy, and it is relevant to analyze environmental variables that affect their performance (Miranda et al., 2016). Startups often face significant barriers to growth, including a lack of access to knowledge, human resources, and efficient forms of financing (Steininger, 2019). 
The general entrepreneurship literature points to supporting factors and infrastructure necessary to promote the entry and development of new companies and startups (Reynolds, 1991; Van de Ven, 1993; Gnyawali \& Fogel 1994, Shane \& Venkataraman, 2000; Bruton et al., 2010). However, there is a lack of studies specifically addressing these factors concerning fintechs, particularly by analyzing their insertion and development in the Brazilian context, which motivated this article.

Therefore, this article aims to identify the facilitators and barriers faced by mobile payment fintechs for their entry and development in the Brazilian context. In order to achieve this goal, a single case study was used as research method. Data collection involved nine companies operating in this industry, and several data sources were accessed, such as secondary documents and data collected in a key business summit.

The research results point out several factors supporting the entrepreneurial activity and market conditions that affect the insertion and development of mobile payment fintechs in the Brazilian context. Some of these factors corroborate the previous literature on entrepreneurship (for example financial support, the need of skilled human resources), while others reveal specific characteristics of the fintech segment that deserve to be considered, such as, for example, the relationship of fintechs with traditional players in the payment sector and the complex legislation that rules this sector.

These results contribute to the startup's literature and, specifically, the literature on fintechs. From a managerial point of view, they can serve as a reference for entrepreneurs and managers of organizations that operate in the payment industry, and also to inform regulations and public policies put forward by the government, the Central Bank, and other regulatory bodies, in order to facilitate the entry and the development of these new companies in the Brazilian market.

\section{LITERATURE REVIEW}

In this section, first, we contextualize fintechs in their ecosystem. After, we approach facilitators and barriers for the entry and development of these companies in the market.

\subsection{FINTECHS AND THEIR ECOSYSTEM}

The term fintech refers to startups that design and deliver financial products and services through the use of technology. These companies affect traditional financial institutions, regulators, customers, and traders in a wide range of services. The diffusion of new digital technologies has been challenging the fundamentals of the highly regulated financial sector, leading to the emergence of non-traditional payment systems, new lines of credit, and digital currencies (Leong et al., 2017). With the development of smartphones, mobile access to the Internet, and the creation of platform-based mobile payment services, mobile payment fintechs have emerged (Lee, Ryu \& Lee, 2019).

For a better understanding of the competitive dynamics of fintechs, it is essential to analyze their ecosystem, which affects the growth of this type of company (Lee \& Shin, 2018). The fintech's ecosystem includes several actors; the main ones are fintechs, entrepreneurs, technology developers, customers, traditional financial institutions, and regulators (Diemers et al., 2015; Lee \& Shin, 2018). 
In this ecosystem (Figure 1), the fintechs are at the center, influencing, and being influenced by the other actors. As examples of fintechs, there are mobile payment companies, financial services providers, crowdfunding solutions providers, capital, and insurance services providers, all of them using digital technologies (Leong et al., 2017). Entrepreneurs contribute with their ideas and take the risks inserting innovative and often disruptive technologies to develop solutions for the fintech ecosystem (Diemers et al., 2015). It is essential to consider, in this analysis, customers of financial products, individuals, or organizations (Lee \& Shin, 2018; Lee, Ryu \& Lee, 2019).

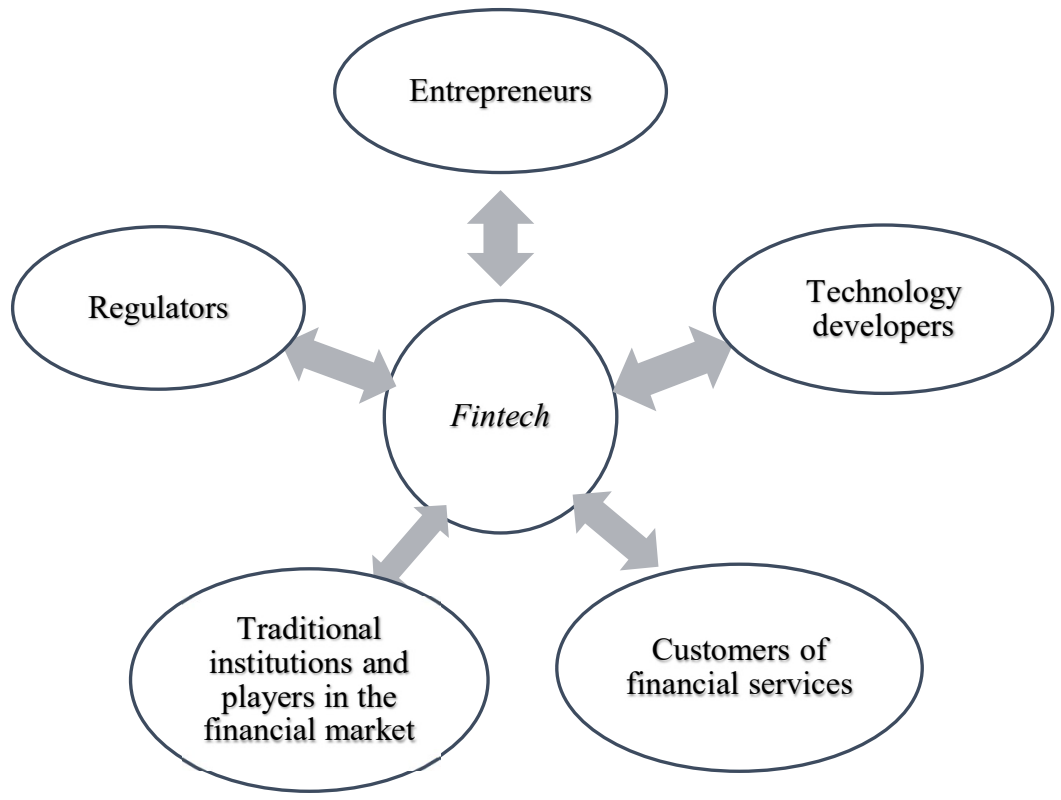

Figure 1. The Fintechs' ecosystem

Source: authors, based on the literature review.

The technology developers provide technology to fintechs to collaborate with the emergence and growth of these companies. They include, for instance, big data analytics and cloud computing providers, cryptocurrency, and social media developers (Gozman, Liebenau \& Mangan, 2018).

The traditional institutions and players in the financial market comprise global and local banks, private equity, and venture capital funds. Many of these financial institutions seek to stimulate their innovation by establishing partnerships with startup fintechs, which can strengthen their competitive position, for example, by shortening the time-to-market (Lee \& Shin, 2018). It is also valid to include in the analysis the regulatory bodies that must implement and monitor compliance with policies and regulations, as well as enhance the development of the ecosystem, encouraging the entrepreneurial activity and hiring technology service companies (Diemers et al., 2015).

We need to consider that the relationship between these agents in the ecosystem contributes or doesn't contribute to the innovation, emergence, and development of fintechs. The agents of this ecosystem can stimulate the economy, facilitate collaboration and competition in the financial sector, and, ultimately, benefit customers in the financial industry (Sussan \& Acs, 2017). 


\subsection{FACILITATORS AND BARRIERS FOR THE CREATION AND DEVELOPMENT OF FINTECHS}

The entrepreneurship literature points to several factors that can act as facilitators or barriers (when absent) for the creation and expansion of new businesses, as detailed next.

Social conditions: The favorable attitude of society towards entrepreneurship and the public support for entrepreneurial activities are necessary to motivate people to start a new business (Reynolds, 1991; Gnyawali \& Fogel 1994, Shane \& Venkataraman, 2000; Bruton et al ., 2010).

Financial support: entrepreneurs need financial assistance to diversify and mitigate the risk of a startup, access venture capital and finance the business growth and expansion (Reynolds, 1991; Van de Ven, 1993; Gnyawali \& Fogel 1994, Shane \& Venkataraman, 2000; Lee et al., 2001; Bruton et al., 2010; Steininger, 2019).

Non-financial support: entrepreneurs need other services in addition to financial assistance, such as support to conduct market research, prepare business plans, networking with other entrepreneurs and agencies and help to obtain funds and loans (Gnyawali \& Fogel, 1994; Bruton et al., 2010; Steininger, 2019).

Legal and regulatory factors: include taxes, bureaucracy to open and maintain businesses, government policies, and bureaucratic procedures (Reynolds, 1991; Gnyawali \& Fogel 1994; Bruton et al., 2010). Entrepreneurs can be discouraged from starting a business if they have to follow too many procedural rules and requirements. Governments can influence market mechanisms and make them work efficiently, eliminating conditions that create market imperfections and administrative rigidity (Gnyawali \& Fogel 1994).

Educational and training conditions: educational and training services are essential for new businesses, especially in emerging market economies, because entrepreneurs may lack the necessary business skills and need specialized human resources (Van de Ven, 1993; Gnyawali \& Fogel 1994; Steininger, 2019). Van de Ven (1993) highlights the importance of institutional arrangements and infrastructure to support R\&D processes and innovation networks for the development of new ventures. Institutional support by entrepreneurship and R\&D support bodies can give legitimacy to startups. Legitimacy involves adapting these companies to the social and economic context and refers to the right to exist and carry out an activity in a certain way (Bruton et al., 2010).

In order to enter the market and develop their business, fintechs also face a set of facilitators and barriers that are specific to their operating context, which is presented next.

Unattended demands: fintechs around the world are providing financial inclusion, or providing access to and active use of financial products to two billion adults without a bank account (Gabor $\&$ Brooks, 2017). The existence of unmet demands for financial services and dissatisfactions from some customers with financial services currently received from traditional players is evident (Iman, 2018). Knowing the needs of these customers and meeting their demand is one of the facilitators of this type of business (Lee, Ryu \& Lee, 2019).

Emergent technologies: Fintechs, through the use of new technologies, achieve cost reduction in transactions, offering value-added services to their current and potential customers (Shaikh, Hanafizadeh \& Karjaluoto, 2017). In financial solutions, questions regarding the identity and private data of clients are fundamental. Protecting them from fraud and crimes, fulfilling obligations, and guaranteeing market integrity is vital to fintechs. Therefore, technology is used not only to reach new customers through the efficiency of services but also to ensure the cybersecurity of operations (Arner et al., 2019). 
Human resources specialized in IT and in the financial market: the existence of developers who master new technologies, have knowledge of the financial sector and can contribute to the construction of new payment solutions is a facilitator for the business. On the other hand, the scarcity of these human resources can be a barrier for new fintechs (Gozman, Liebenau \& Mangan, 2018).

Partnerships between fintechs: a healthy ecosystem that enables the development of partnerships between fintechs to develop solutions quickly and at lower costs is considered as one of the main facilitators for fintechs to compete in a market of big, traditional players. The use of complementary technologies and services to build a customer-focused solution is the strategy used by several startups. Fostering a network in which entrepreneurs relate to each other and can form partnerships is key to support the development of these companies (Diemers et al., 2015).

Big companies and traditional players: Fintechs using cutting edge technology and focusing on serving customers have competitive advantages. Thus, traditional and large financial institutions have been facing these new competitors in several ways, mainly attempting to develop technological innovations and eliminating processes that do not create value (Murshudli \& Loguinov, 2019). Traditional banks are also creating startup acceleration programs, collaborating with fintechs, and creating venture capital funds to invest in these companies (Folwarski, 2018). Understanding how these traditional, big players operate in the market and use their structures to develop and scale new solutions can transform a possible barrier into a business facilitator for fintechs (Lee $\&$ Shin, 2018). On the other hand, large companies can also take protective measures to defend their market reserves, creating new barriers (Romānova \& Kudinska, 2016).

Regulations in the Financial industry: the financial sector develops regulations to ensure the security of transactions and minimize fraud. Understanding the legislation and applying it properly is a challenge for new entrants (Diemers et al., 2015). However, the development of financial technologies and the emergence of fintechs is changing the market and forcing traditional financial institutions to adapt their operations and, consequently, it creates gaps in the existing legislation. Regulatory bodies need to regulate the market to protect customers and provide free competition. Failures by these agents add risks to operations and generate legal uncertainty, but excessive regulations can restrict innovations and the number of new entrants (Folwarski, 2018). Caution tends to overcome risks and reinforce the status quo, and new technologies may struggle to reach the market in a timely and efficient manner. Legislative and normative planning needs to be more proactive, dynamic, and responsive (Fenwick, Kaal \& Vermeulen, 2018).

Chart 1 summarizes the support factors for entrepreneurial activities and market conditions, identified in the literature, that affect the creation and development of new ventures, some specifically related to fintechs. These factors will later be considered in the discussion of the research results (section 5). 
Chart 1

Potential facilitators and barriers to the development of fintechs

\begin{tabular}{|c|c|c|}
\hline Factor & Definition & Source \\
\hline Social conditions & $\begin{array}{l}\text { A favorable attitude and support of society } \\
\text { towards entrepreneurship. }\end{array}$ & $\begin{array}{l}\text { Reynolds, 1991; Gnyawali \& Fogel, } \\
\text { 1994, Shane \& Venkataraman, 2000; } \\
\text { Bruton et al., } 2010\end{array}$ \\
\hline Financial support & $\begin{array}{l}\text { Assistance and financial resources to } \\
\text { diversify and mitigate the risk of a startup, } \\
\text { finance the creation and expansion of } \\
\text { businesses. }\end{array}$ & $\begin{array}{l}\text { Reynolds, 1991; Van de Ven, 1993; } \\
\text { Gnyawali \& Fogel 1994, Shane \& } \\
\text { Venkataraman, 2000; Lee et al., 2001; } \\
\text { Bruton et al., 2010; Steininger, } 2018\end{array}$ \\
\hline Non-financial support & $\begin{array}{l}\text { Assistance in market research, preparation } \\
\text { of business plans, networking }\end{array}$ & $\begin{array}{l}\text { Gnyawali \& Fogel ,1994; Bruton et al., } \\
\text { 2010; Steininger, } 2018\end{array}$ \\
\hline $\begin{array}{l}\text { Training and skilled } \\
\text { human resources }\end{array}$ & $\begin{array}{l}\text { Educational and training services, } \\
\text { developers who master new technologies } \\
\text { and know the financial sector. }\end{array}$ & $\begin{array}{l}\text { Van de Ven, 1993; Gnyawali \& Fogel } \\
\text { 1994; Ozman; Liebenau; Mangan, 2018; } \\
\text { Steininger, } 2018\end{array}$ \\
\hline $\begin{array}{l}\text { Legal and regulatory } \\
\text { factors }\end{array}$ & $\begin{array}{l}\text { Taxes, bureaucracy to open and maintain } \\
\text { businesses, government regulations, } \\
\text { policies and procedures. }\end{array}$ & $\begin{array}{l}\text { Reynolds, 1991; Gnyawali \& Fogel } \\
\text { 1994; Bruton et al., 2010; Diemers et al., } \\
\text { 2015; Folwarski, 2018; Fenwick, Kaal \& } \\
\text { Vermeulen, } 2018\end{array}$ \\
\hline $\begin{array}{l}\text { Support infrastructure } \\
\text { for R\&D processes }\end{array}$ & $\begin{array}{l}\text { Institutional arrangements to support } \\
\text { R\&D processes and innovation networks }\end{array}$ & Van de Ven (1993) \\
\hline Unattended demands & $\begin{array}{l}\text { Demands for new and more effective } \\
\text { financial services and dissatisfaction of } \\
\text { some customers with current services }\end{array}$ & $\begin{array}{l}\text { Iman, 2018; Lee, Ryu \& Lee, 2019; } \\
\text { Gomber et al., } 2018\end{array}$ \\
\hline $\begin{array}{l}\text { Emergent } \\
\text { Technologies }\end{array}$ & $\begin{array}{l}\text { New technologies make it possible to } \\
\text { reach new customers and guarantee the } \\
\text { security of operations }\end{array}$ & $\begin{array}{l}\text { Haikh; Hanafizadeh \& Karjaluoto, } 2017 \text {, } \\
\text { Arner et al., } 2019\end{array}$ \\
\hline $\begin{array}{l}\text { Business partnerships } \\
\text { between fintechs }\end{array}$ & $\begin{array}{l}\text { Partnerships between fintechs to develop } \\
\text { solutions fast and at lower costs. }\end{array}$ & Chetty et el., 2019; Diemers et al., 2015. \\
\hline $\begin{array}{l}\text { Big companies and } \\
\text { traditional players }\end{array}$ & $\begin{array}{l}\text { Partnerships with big and traditional } \\
\text { players can be an opportunity, but } \\
\text { conflicts of interest in the market are } \\
\text { barriers. }\end{array}$ & $\begin{array}{l}\text { Romānova \& Kudinska, 2016; Lee \& } \\
\text { Shin, 2018; Murshudli; Loguinov, 2019; } \\
\text { Folwarski, } 2018 .\end{array}$ \\
\hline
\end{tabular}

Source: Prepared by the authors based on the literature review.

\section{METHOD}

The research adopted the single case study (Yin, 2015) method, whose unit of analysis was the segment of mobile payment fintechs in Brazil. The choice of the case study method is justified for several reasons (Eisenhardt, 1989; Yin, 1989), such as (a) the analysis of a contemporary phenomenon - mobile payments offered by fintechs; (b) a study conducted in a real context the Brazilian payment system; (c) the search for depth and understanding of the history and context of the problem identified; and (d) the use of multiple sources of evidence, allowing triangulation of data.

As recommended by the case study method (Eisenhardt, 1989), data was collected from different sources and in different ways, such as document analysis, interviews, and participant observation. Data collection was carried out in 3 steps (Figure 2), detailed next. 


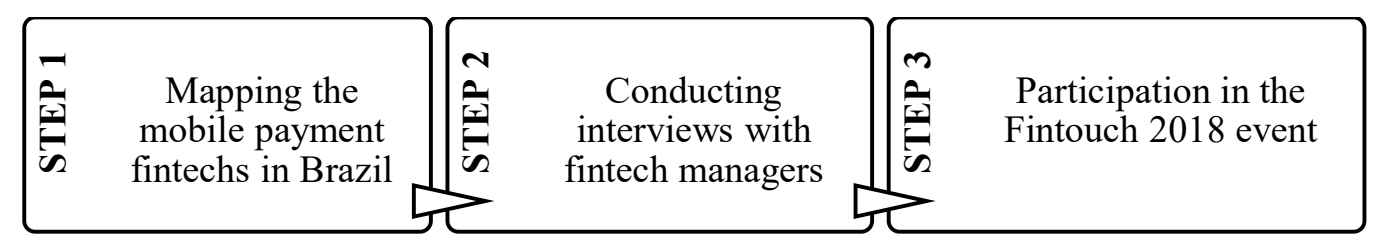

Figure 2. Steps in the data collection

Source: research data

Step 1: Mapping the mobile payment fintechs in Brazil - To identify the mobile payment fintechs operating in Brazil, an advanced Google search for the term "mobile payments" was carried out on November $30^{\text {th }}, 2017$, and we considered the first 30 pages of results, corresponding to 300 websites, which were analyzed. In this analysis, a fintech radar publication was found, published in November 2017, by FintechLab, a hub for connecting and promoting the Brazilian fintech ecosystem. With the radar in hand, we searched for information from the fintechs in the payment sector depicted in the radar to identify those that offered mobile payment solutions. We performed this search via social networks (Facebook and Instagram) and in the companies' websites, identifying 34 mobile payment fintechs. The first contact with these 34 companies occurred via e-mail or Messenger; a letter presenting the research was sent, and an interview was requested. During the interviews, we searched for contact with other companies, following the snowball technique. Of all the contacted companies, nine agreed to participate in this research.

Step 2: In this step, interviews were conducted with the fintechs' managers. A script containing 19 questions was used as a guide; nine questions were specific to the company interviewed, and ten referred to the Brazilian payment sector. The script was used to ensure that the essential topics were questioned with the interviewees. However, in all interviews, additional and complementary questions were asked to detail the answers provided. The interviews were conducted via video/ audio calls on Skype or Google Hangouts. The profiles of participating companies are shown in Table 1. All interviews were recorded and later transcribed for content analysis.

Table 1

Profile of participating fintechs

\begin{tabular}{|c|c|c|c|c|c|c|}
\hline & Foundation & Property & $\begin{array}{l}\text { Number of } \\
\text { employees }\end{array}$ & Company headquarters & Market & $\begin{array}{l}\text { Interview } \\
\text { duration }\end{array}$ \\
\hline E1 & 2016 & 2 partners & 5 & São Paulo - Brazil & Brazil & $01: 03: 45$ \\
\hline E2 & 2015 & 6 partners & 20 & Countryside of Brazil & Brazil & 00:38:04 \\
\hline E3 & 2013 & $\begin{array}{l}\text { Familiar } \\
\text { holding }\end{array}$ & 6 & Countryside of Brazil & $\begin{array}{c}\text { Countryside of } \\
\text { Brazil }\end{array}$ & $01: 10: 15$ \\
\hline E4 & 2013 & 7 partners & 160 & Countryside of Brazil & Latin America & $01: 00: 32$ \\
\hline E5 & 2012 & 30 investors & 150 & São Paulo - Brazil & Brazil & $00: 35: 50$ \\
\hline E6 & 2015 & 3 partners & 9 & Countryside of Brazil & Brazil & $00: 44: 34$ \\
\hline E7 & 2015 & Not informed & 15 & London and Sáo Paulo & - & $00: 22: 52$ \\
\hline E8 & 2013 & 2 members & 20 & São Paulo - Brazil & Brazil & - \\
\hline \multirow[t]{2}{*}{ E9 } & 2017 & Not informed & Not informed & São Paulo - Brazil & Brazil & $00: 19: 56$ \\
\hline & & & & & & $05: 55: 48$ \\
\hline
\end{tabular}

Source: research data. 
Step 3: Participation in the Fintouch 2018 event - The Fintouch is the largest Fintech event in Latin America. It happened in August 2018, in São Paulo (Brazil); the first author of the paper attended 35 talks/presentations in this event, and 3 were selected for recording (with a total duration of 01:32:00). These talks/presentations addressed topics directly related to the research. Table 2 presents the details of the data collection performed at this event.

The interviews and talks were recorded and later transcribed. The transcripts were imported into the NVivo software, which supported the data analysis process, in which we used the open coding technique. Initially, the materials were coded in "case nodes", and for the fintechs, each file was named with a code (01 to 09) followed by the name of the company - Ex .: 01_Fintech1 - while the Fintouch talks were classified according to the player represented in that speech - Ex.: Central Bank, CVM, ABFintechs, among others. The organization of the data (case nodes and sources within NVivo) is shown in Figure 3.

Table 2

Details of data collected at the event (Fintouch 2018)

\begin{tabular}{lllc}
\hline Talk/Presentation & \multicolumn{1}{c}{ Title } & \multicolumn{1}{c}{ Keynote Speakers } & Duration \\
\hline P1 & $\begin{array}{l}\text { Brazil at the forefront of } \\
\text { Fintech regulation }\end{array}$ & $\begin{array}{l}\text { Central Bank Representative } \\
\text { CVM Representative } \\
\text { ABfintechs representative } \\
\text { Central Bank Representative }\end{array}$ & $0: 30: 01$ \\
& $\begin{array}{l}\text { SANDBOX: Building the } \\
\text { Brazil of the future }\end{array}$ & $\begin{array}{l}\text { CVM Representative } \\
\text { SUSEP Representative } \\
\text { ABFintechs representative }\end{array}$ & $0: 30: 44$ \\
P3 & $\begin{array}{l}\text { Withdraw: The challenge of } \\
\text { transforming digital money } \\
\text { into cash in a country with the } \\
\text { size of Brazil }\end{array}$ & $\begin{array}{l}\text { Saque \& Pague representative } \\
\text { ABFintechs representative } \\
\text { ABFintechs representative }\end{array}$ & \\
\hline \multicolumn{1}{c}{3} & \multicolumn{1}{c}{10} & $0: 31: 44$ \\
\hline
\end{tabular}

Source: research data

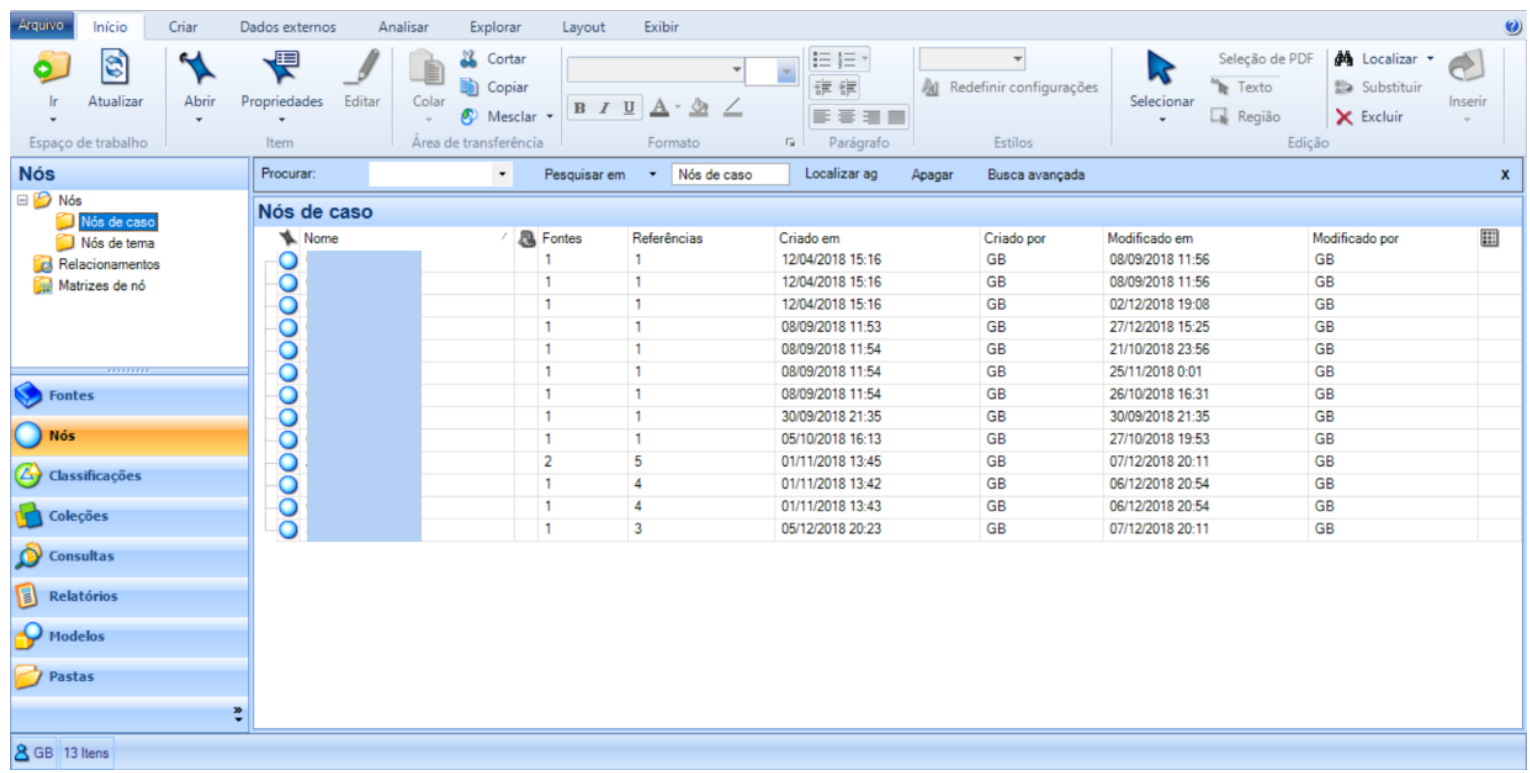

Figure 3. Research database. Source: research data. 
After coding the content in sources and case nodes, assigning each document to a specific player, we proceeded with the open coding process, which divides the qualitative data into discrete parts, examining them closely and comparing them for similarities and differences, aiming to leave them open to all possible theoretical directions pointed out by the literature (Saldaña, 2009).

With this rationale, the content of each collected document was analyzed and coded into a category or subcategory (theme node, in NVivo), these categories were data-driven, without being linked, at first, to theoretical concepts. A code, in qualitative research, is, in most cases, a short word or phrase that symbolically assigns an attribute that captures the essence and represents a lot of visual or language-based data, which can consist of interview transcripts, field notes of participant observations, periodicals, documents, literature, artifacts, photographs, videos, websites, e-mails, among others. (Saldaña, 2009).

As the number of codes can accumulate quickly and change as the analysis progresses, Saldaña (2009) suggests keeping a record of the codes in a file called "codebook", which contains the compilation of all codes, content descriptions, and a brief example of data coded. In the first round of coding, 35 categories and 16 subcategories were created, then reviewed and reorganized, generating the final codebook, consisting of 12 categories and 55 subcategories. Figure 4 shows the layout of categories and subcategories in NVivo, in the form of "theme nodes".

The categories, as they emerged from the data, made it possible to understand the profile of the mobile payment fintechs, their history of entry in the market, and their development, as well as facilitators and barriers faced in these processes. These categories were crossed with the categories pointed out by the literature (section 2) later in the process.

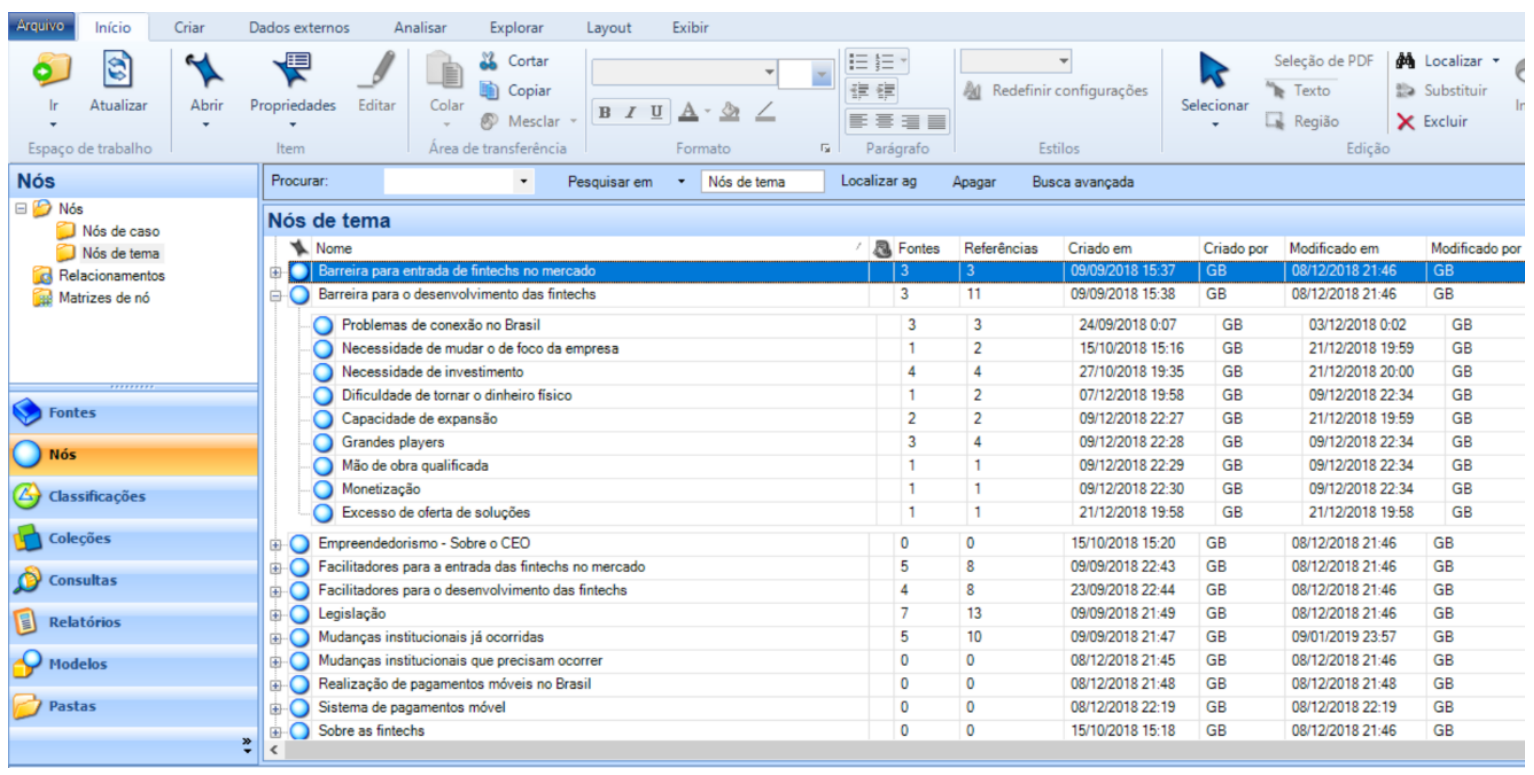

Figure 4. Data categories (theme nodes) in NVIVO software.

Source: research data.

\section{RESULTS}

In this section, we analyze the profile of the studied fintechs; then, we explore the factors that facilitated and hindered their entry into the Brazilian market. 


\subsection{THE PROFILE OF THE MOBILE PAYMENT FINTECHS STUDIED}

Initially, the managers of the fintechs were asked about their companies' differentials and value proposition. Chart 2 shows that, except for E9, they have a clear value proposition and focus on specific segments and niches in the Brazilian market.

The characteristics of the companies (Chart 2) are aligned with the characteristics of the fintechs found in a survey conducted by the Brazilian Association of Fintechs (ABFintechs) and presented at Fintouch 2018. Most of them seek to offer highly focused solutions (transfer of funds, prepaid cards, among others), based on disruptive technologies (replacement of the credit/debit card machines with mobile phone applications, validation of payments via selfies, etc.) and aimed at an underserved public (unbanked population, self-employed professionals and small businesses).

Chart 2

Differentials and fintech value proposition

\begin{tabular}{|c|c|c|c|}
\hline & Solution offered & Competitive edge & Value Proposition \\
\hline E1 & $\begin{array}{l}\text { Transfers of money via } \\
\text { an app }\end{array}$ & $\begin{array}{l}\text { - Convenience; } \\
\text { - Ease of making transfers of funds } \\
\text { (pay and receive). }\end{array}$ & $\begin{array}{l}\text { Make financial transactions easier, less } \\
\text { bureaucratic, and cheaper. }\end{array}$ \\
\hline E2 & $\begin{array}{l}\text { Use of mobile phones } \\
\text { as payment and top-up } \\
\text { machine }\end{array}$ & $\begin{array}{l}\text { - Focus on freelancers and small } \\
\text { businesses; } \\
\text { - No need for a credit/debit card } \\
\text { machine; } \\
\text { - Focus on the point of sale. }\end{array}$ & $\begin{array}{l}\text { Enable self-employed and small } \\
\text { businesses to resell cell phone top- } \\
\text { ups, receive bills, among others, } \\
\text { through a mobile application. }\end{array}$ \\
\hline E3 & Mobile food voucher & $\begin{array}{l}\text { - Easy to use platform, free of charge } \\
\text { and without loyalty fees; } \\
\text { - Lower transaction costs compared } \\
\text { to similar offers. }\end{array}$ & $\begin{array}{l}\text { Offering a simple platform, easy to } \\
\text { use and less expensive }\end{array}$ \\
\hline E4 & Prepaid card & $\begin{array}{l}\text { - Tokenization: several ways to make } \\
\text { payments (bracelet, watch, cards, } \\
\text { rings); } \\
\text { - Agility and innovation. }\end{array}$ & $\begin{array}{l}\text { Offering innovative, agile, and } \\
\text { focused payment solutions. }\end{array}$ \\
\hline E5 & Prepaid card & $\begin{array}{l}\text { - Ease of card acquisition; } \\
\text { - Transfers between cards. }\end{array}$ & $\begin{array}{l}\text { Offering, through a prepaid card, a } \\
\text { simplified account to customers. }\end{array}$ \\
\hline E6 & $\begin{array}{l}\text { Smartphone payments } \\
\text { and transfers }\end{array}$ & $\begin{array}{l}\text { - Transforms the smartphone into a } \\
\text { digital wallet; } \\
\text { - Use of the cell phone to receive } \\
\text { money; } \\
\text { - Reduced transaction time from } 25 \\
\text { to } 4 \text { seconds. }\end{array}$ & $\begin{array}{l}\text { Offer a solution that speeds } \\
\text { payments, eliminating the need for } \\
\text { credit/debit card machines. }\end{array}$ \\
\hline E7 & $\begin{array}{l}\text { Validation of payments } \\
\text { via facial recognition }\end{array}$ & $\begin{array}{l}\text { - Proprietary Technology } \\
\text { - Facial recognition features }\end{array}$ & $\begin{array}{l}\text { Offering a facial recognition solution } \\
\text { with a focus on payments and } \\
\text { financial services }\end{array}$ \\
\hline E8 & $\begin{array}{l}\text { Payments and transfers } \\
\text { via an app }\end{array}$ & $\begin{array}{l}\text { - Convenience and facility to save } \\
\text { and use money. }\end{array}$ & $\begin{array}{l}\text { Enable the unbanked population to } \\
\text { use financial services in an easy, fast } \\
\text { and secure way }\end{array}$ \\
\hline E9 & Digital Card & $\begin{array}{l}\text { - Credit Card without credit } \\
\text { analysis; } \\
\text { - Excellent customer service. }\end{array}$ & $\begin{array}{l}\text { The company is still defining in } \\
\text { which niche to focus on, it does not } \\
\text { have a defined value proposition. }\end{array}$ \\
\hline
\end{tabular}

Source: research data. 


\subsection{ENTRY OF MOBILE PAYMENT FINTECHS INTO THE BRAZILIAN PAYMENT SECTOR}

The research data shows that the fintechs' managers perceive a higher number of barriers than facilitators to enter the market; they are detailed next.

\subsubsection{Barriers of entry in the mobile payment sector}

The barriers to entry into the Brazilian payment market highlighted by the fintechs are compliance with legislation, lack of regulation, investment needs and difficulty in raising money to open a business, conflict with major players, difficulty in finding strategic partners, the users' behavior and the fintech geographic location.

The main barrier refers to compliance with legislation. It is related to the difficulty in understanding and complying with current legislation, dealing with specific issues to be met according to the company's niche, and the lack of specific legislation to rule the work of fintechs. This difficulty was faced by the fintechs that entered the market before 2013 when the Law 12.865/13 (current legislation on payment arrangements and institutions) was published. E3 highlights the difficulty in understanding the regulations: "I am a trained lawyer, and I spent a long time studying, and I said that those who are not lawyers cannot understand this, they will have to hire a legal expert, it will be expensive for them to pay for a professional analysis".

Since the Law 12.865/2013 does not regulate the fintechs, but only the payment system and arrangements in Brazil, some interviewees affirm that they work without knowing the "rules of the game" which will be imposed by specific regulation of fintechs. E9's report makes this situation clear: "We still operate without regulation, hoping that regulation will come or it will start to take effect, we already operate without waiting for it".

However, although the legislation is considered a possible barrier to the entry of fintechs into the market, E7 is in favor of the Central Bank (BC) 's firm stance to prevent unprepared or malicious companies from entering the market. He justifies his opinion: "When you have a business, you will try to do your best to assure that new entrants follow the rules, as have happened, for example, with taxi drivers against Uber. If it does not happen, anyone gets in the market, and there are malicious people around... ".

A second element mentioned as a barrier by the interviewees refers to investment needs, and the difficulty of raising money to open the business. Respondents state that, because fintechs are small, unknown in the market, and with low profitability at the beginning of their operation, investors overlook them. These features make the fundraising process more difficult, as they are, in general, startup companies with low social capital. Respondents also reported that, by offering payment solutions, fintechs compete with banks and financial institutions already consolidated and with significant profits, which makes investors choose these larger companies to invest. According to E1: "To conquer investors, undoubtedly, because we fight with the largest players in the country, with the companies with the highest profits. So if someone is going to invest money somewhere, it's in the big banks".

The conflict of interests with major players in the market, such as banks, financial institutions, and credit card companies, was also highlighted as a barrier to entry into the market. The interviewees' reports refer to issues such as abuse of power, monopoly, or even boycotts performed by major players in the market, as reported by E5:

"We wanted to make it possible for people to top up our cards in their bank accounts or via an electronic bill. We already had closed accounts, an account blocked by the bank, a bank that canceled the electronic 
In line with this, E7 highlights that the big players can organize themselves and impose market norms, such as, for example, making it difficult for new companies to enter the payment sector and forcing them to establish partnerships for card issuance, forcing the company to become a sub-acquirer of an already consolidated acquirer or card issuer operating in the market. E9 points out that the choice of the credit card issuer partner is not so simple, because the fintech promises an innovative and simplified financial solution, while most acquirers and credit card operators are not aligned with this strategy. Thus, the choice of a strategic partner that offers services with high quality and agility is also a barrier to entry in the Brazilian payment sector.

Respondents claim that potential user's behavior, precisely, a cultural issue of mistrust in new forms of payments, still affects the acceptance and adoption of mobile payments, being a barrier to entry. E6's comment clarifies this issue:

"So, Brazil is still in its infancy in terms of smartphone payments. [...] Still, there is a very strong cultural issue. People are used to a process that they have been doing for years. So this question ... this change of habit, this behavioral issue, in my view, is the main challenge".

Finally, one last barrier highlighted by the only company located outside the Rio-São Paulo area concerns its geographic location. E6's report shows that, although the location does not impede the operation of his fintech, there is some resistance by other players because the company is headquartered in Santa Catarina (a state in South Brazil): "... it made these players to look us with a suspicious mind, "gee, why do three kids there, at the countryside of Santa Catarina, want to do a business that few people managed to do?"

\subsubsection{Facilitators for entry into the market}

The facilitators for the entry of mobile payment fintechs into the Brazilian payment sector, highlighted by the interviewees, are technology, the convenience of the payment solution offered, knowledge of the payment sector, the possibility of offering more focused solutions, and differentiated services. The primary facilitator for the entry of fintechs into the market is technology, with a consensus among respondents that there is no fintech without technology:

\footnotetext{
"If there is a reason why any fintech exists, it is because of the technological base ... there is no way to take away the technology, the role of technology, the technology is the product, do you understand? It is $100 \%$ technology, I can't even think much, the role of technology is the main one "(E1)

"It is the company's core, the company's DNA, it is based and subsidized by technologies". (EG)
}

Another aspect highlighted as a facilitator refers to the convenience of the payment solution offered, bringing easier, agile, and less bureaucratic means of payments than traditional solutions offered in the market. As the main factors linked to convenience, the interviewees emphasize the ease of making payments and transferring money in just one click; or without the need to carry a credit card, using only the mobile phone. As new mobile payment solutions emerge, this payment method is becoming better known, which is a facilitator. For example, according to E3, the emergence and rapid expansion of NuBank has made fintechs more popular in Brazil, and the arrival of worldwide-consolidated payment solutions, such as Samsung Pay and Apple Pay, has enabled users to use new solutions more quickly. 
Finally, other facilitators reported by the interviewees - more focused solutions and differentiated services - complement each other, as it is a characteristic of fintechs to select a specific market problem and solve it, through a specialized solution. According to E6: "what we propose to deliver

[...] is speedy payments. Obviously, there are other benefits, but we are very convinced that if you want to do everything, in the end, you do nothing at all".

Regarding the customer services, E9 stated that differentiated service, with a proposal for excellence, makes a difference and can be seen as a facilitator for the entry of fintech in the financial market since it is common to register several complaints about the services provided by traditional financial institutions.

\subsection{The DeVElopment of MOBILE PAYMENT FinTECHS IN THE BRAZILIAN MARKeT}

After entering the market, fintechs face a set of facilitators and barriers for their development and scale-up, as detailed next.

\subsubsection{Barriers to the development of mobile payment fintechs}

The following barriers were identified for the development of fintechs: difficulty in fundraising, capacity to scale up, connection problems, conflict with major players, over-supply of payment solutions, lack of qualified human resources, difficulties in monetization, change in their business focus and difficulties related to the need of use of physical money.

The main barrier highlighted by the companies refers to the need for investments and difficulties in fundraising. E6's report clarifies this issue: "as we work with assets, which is money, fintechs need to have almost the same facility that banks have to raise funds. For example, for a traditional bank to raise capital, with agencies ... federal institutions, it is much easier". Fundraising from public investment agencies has been difficult for fintechs, and they also face difficulties attracting private venture capital and other types of investors. They claim that it is related to a cultural issue: Brazilian investors resist investing in high-risk businesses, such as fintechs.

The difficulty of fundraising is related to the second barrier highlighted, which refers to the expansion of fintechs. Respondents say that while trying to expand their business, they try to keep the work team lean to minimize costs. According to E2: "[...] we try to scale up without generating a lot of personal customer services, the best thing is to support customers to be able to download and do the entire onboarding cycle autonomously".

A third barrier concerns the lack of access to a stable Internet connection in different parts of Brazil, making it difficult and, in many cases, impossible for customers to make mobile payments via smartphones. Thus, some companies that started their businesses focusing on user-oriented solutions had to rethink and propose a new model, focusing on physical points of sale where Internet access is available, and the operations do not depend on the mobile network, as in the case of E2, and of E3, who developed a payment model using text messages (SMS).

The conflict with major players in the sector was previously mentioned as a barrier to the entry of mobile payment fintechs in the market. It was mentioned again as a barrier to their development and scale-up. E5 says that there is still a lot of power concentration in the hands of the banks. However, E6 states that new competitors have made major players "feel uncomfortable," they need to seek for new technological solutions and provide a more qualified service: "I see that the competition itself is quite healthy and who ends up being benefited is always the customer".

Acceleration projects offered by major players were also highlighted in the interviews. However, according to the interviewees, although the idea of acceleration is interesting and the expertise of 
the big players is useful for the development of fintechs, there are hidden agendas on the part of the big players, which discourages partnerships with them. According to E3: "So you see, they go and support you right away, but they launch a competitor in the end. So I confess that I am always a little afraid of these big companies and these projects, and I sign up in few initiatives proposed by them".

Another barrier is related to the scarcity of qualified human resources to work in the development of fintechs. E5 states that the demand for advanced software developers has been higher than the supply of professionals: "[...] today there are so many people wanting to start this type of business that the supply of human resources does not meet the demand, so today developing new solutions is a big challenge".

The difficulty of monetization is also a barrier to the development of fintechs. Respondents point out difficulties in defining the amount to be charged for the provision of services, especially since people do not want to pay for financial services at all. Thus, it is clear that fintechs need to be creative in their value proposition to differentiate themselves, and they work with small profit margins. According to E9, the profit to fintechs when carrying out some financial transactions is usually cents. Several fintechs had to change the focus of their business after entering the market, due to several aspects, such as the non-acceptance of the payment solution by potential users, lack of availability for Internet connections needed to carry out transactions, among others.

Finally, the difficulty of transforming the values transferred via mobile applications into physical currency to be withdrawn was also reported as a difficulty faced by fintechs. Some partnership possibilities to solve this issue are centralized in the hands of major players, such as banks, which can make the operation more expensive.

\subsubsection{Facilitators for the development of mobile payment fintechs in Brazil}

The facilitators identified for the development of the fintechs were: networking, partnership with other companies, technology, collaboration, the union between fintechs, and the work of ABFintechs. The first factor, according to E3, refers to networking. He reports that he strategically chose to start the business in his hometown, where he knows many people, which increases the chances of establishing partnerships with companies. The initial strategy adopted by the company worked; the networking has facilitated its expansion.

A second facilitator refers to the partnership with major players. For E3, today it is possible to evolve and scale up a fintech more quickly because some major players in the financial sector are willing to form alliances and cooperate with innovative companies, as highlighted: "[...] you can evolve faster today, companies are more willing to collaborate in partnerships. So, I kind of want to start and I'm going to contact Visa to launch this business model and today Visa is going to be more open to this type of partnership than it would have been 4 years ago when we started". However, as already discussed, the interviewees emphasize that this type of partnership is not always beneficial, because sometimes big companies impose rules that make it difficult to operationalize the partnerships. Among these rules, the imposed priority in future stock purchases and the nonsigning of confidentiality contracts in innovations projects stand out. Therefore, many fintechs choose to follow their operations in the market independently.

A third facilitator for the development of fintechs is technology; E6 makes clear its role for the development and scale-up of the business: "So today, for example, if we ... we have five thousand... 5,600 customers, if we want to scale up to 15,000, we will achieve this new scale through technology and the technology gives us this power". Technology also plays a fundamental role in reducing operational costs, such as issuing cards and sending them by mail. 
Another facilitator for the development of fintechs refers to the collaboration and union among these companies, which has generated, for example, the Brazilian Association of Fintechs, ABFintech. This institution has an important role in mobilizing and organizing the interests of these companies, serving as their representative entity to agencies such as BC and CVM. There is consensus among the interviewees about the importance and relevance of the association for the development of fintechs. ABFintechs facilitates, especially, the dialogue with regulatory bodies. E5 reports that "the association makes noise and, yes, they can work with the agencies, with the market, to expose our ideas, I have no doubt", this was complemented by E3: "before ABFintechs our work was a very fragmented, each one accessed their own contacts".

\section{DISCUSSION}

There was a convergence between the facilitators and barriers identified in the literature and our study. Chart 3 crosses the factors mentioned in the literature (Chart 1) with the empirical data; we discuss this result next.

Regarding the social conditions (Reynolds, 1991; Gnyawali \& Fogel 1994, Shane \& Venkataraman, 2000; Bruton et al., 2010), the research data did not provide evidence for the importance of social support for fintechs by the Brazilian society as a critical factor for the development of this type of business. However, the population's knowledge about mobile payments, mainly due to the services offered by major global players, contributes to the social acceptance and diffusion of this type of service. Cultural barriers on the part of Brazilian investors (usually conservative) is also a social factor that deserves to be considered.

The financial support (Reynolds, 1991; Van de Ven, 1993; Gnyawali \& Fogel 1994, Shane \& Venkataraman, 2000; Lee et al., 2001; Bruton et al., 2010; Steininger, 2019) is crucial for both the entry in the market and the development/scale up of fintechs. Because they are nascent companies in a mature and highly institutionalized market, there are difficulties in gaining legitimacy, which makes it difficult to obtain resources (Bruton et al., 2010). As a result, these companies face difficulties to fundraise and expand their operations.

Regarding the need for non-financial support, although this factor was not directly pointed out by the interviewees, it was found that they face difficulties in thinking about the business model, especially regarding the value proposition and the forms of monetization of their services. There is a wide market willing to consume new financial services, however, knowing the real needs of potential customers and having a clear value proposition is essential (Lee, Ryu \& Lee, 2019). Although some initiatives promoted by major players, through startup accelerators, offer this non-financial support, some conditions imposed by these larger players are unfavorable to fintechs. Thus, non-financial support (such as consultancy or managerial training) that can help fintechs to overcome these challenges is needed to promote this segment.

This factor is related to the need of training and specialized human resources (Ozman, Liebenau \& Mangan, 2018; Steininger, 2019), as the development of fintechs depends on the people who work in this segment, who need to have advanced knowledge both in the areas of technology and software development, and also specialization in the financial market. There is a shortage of these qualified human resources in the Brazilian context, which can hinder the fintechs' development. 
BBR

Chart 3

Facilitators and barriers faced by fintechs in the Brazilian context

\begin{tabular}{|c|c|c|}
\hline \multirow{2}{*}{ Factors } & \multicolumn{2}{|c|}{ Entry in the Market and development/scale-up of fintechs } \\
\hline & Barriers & Facilitators \\
\hline Social conditions & $\begin{array}{l}\text { - Brazilian investors' culture - investments in } \\
\text { fintechs are mostly performed by foreign } \\
\text { investors }\end{array}$ & $\begin{array}{l}\text { - Knowledge of the mobile payment } \\
\text { sector }\end{array}$ \\
\hline Financial support & $\begin{array}{l}\text { - Investment needs/ Difficulties in fundraising } \\
\text { - Low scale up capacity } \\
\text { - Difficulty in monetizing the offered solution }\end{array}$ & \\
\hline $\begin{array}{l}\text { Non-financial } \\
\text { support }\end{array}$ & $\begin{array}{l}\text { - Lack of support for strategic orientation } \\
\text { (changes in business focus) } \\
\text { - Lack of support for developing the business } \\
\text { model }\end{array}$ & $\begin{array}{l}\text { - Non-financial support received } \\
\text { from accelerators }\end{array}$ \\
\hline $\begin{array}{l}\text { Lack of qualified } \\
\text { human resources }\end{array}$ & $\begin{array}{l}\text { Lack of qualified HR - software developers and } \\
\text { professionals who know the financial sector }\end{array}$ & \\
\hline $\begin{array}{l}\text { Legal and } \\
\text { regulatory issues }\end{array}$ & $\begin{array}{l}\text { - Lack of specific regulation for fintechs. } \\
\text { - Difficulties in understanding current legislation } \\
\text { regarding the financial system. }\end{array}$ & \\
\hline $\begin{array}{l}\text { Infrastructure to } \\
\text { support R\&D } \\
\text { processes }\end{array}$ & - & - \\
\hline $\begin{array}{l}\text { Unattended } \\
\text { customers }\end{array}$ & $\begin{array}{l}\text { - Resistance of some potential users against the } \\
\text { new means of payment. }\end{array}$ & $\begin{array}{l}\text { - Convenience of the payment } \\
\text { solution offered } \\
\text { - Possibility to offer more focused/ } \\
\text { niche solutions } \\
\text { - Specialized service }\end{array}$ \\
\hline $\begin{array}{l}\text { Emergent } \\
\text { technologies }\end{array}$ & $\begin{array}{l}\text { - Limitations of public ICT infrastructure } \\
\text { (Internet connection) } \\
\text { - Difficulties in transforming funds in physical } \\
\text { currency }\end{array}$ & $\begin{array}{l}\text { - ICT/mobile technology as the basis } \\
\text { for fintech's existence }\end{array}$ \\
\hline $\begin{array}{l}\text { Business } \\
\text { partnerships among } \\
\text { fintechs }\end{array}$ & & $\begin{array}{l}\text { - Business networking between } \\
\text { fintechs } \\
\text { - Business partnerships between } \\
\text { fintechs }\end{array}$ \\
\hline $\begin{array}{l}\text { Relationship with } \\
\text { large players }\end{array}$ & $\begin{array}{l}\text { - Large players create barriers of entry for fintechs } \\
\text { in the market } \\
\text { - Difficulties to access business partners with } \\
\text { strategic alignment }\end{array}$ & $\begin{array}{l}\text { - Large international players help to } \\
\text { diffuse mobile payments } \\
\text { - Possibility of business partnerships } \\
\text { with major players }\end{array}$ \\
\hline $\begin{array}{l}\text { Geographic } \\
\text { location* }\end{array}$ & $\begin{array}{l}\text { - Fintechs that are far from large financial centers } \\
\text { have more difficulties in making businesses/ } \\
\text { gaining legitimacy }\end{array}$ & \\
\hline
\end{tabular}

(*) This factor has emerged from empirical data

Source: Research data 
Among the knowledge necessary for these specialized professionals, the knowledge of the legislation is a factor highlighted in the entrepreneurship literature (Reynolds, 1991; Gnyawali \& Fogel 1994; Bruton et al., 2010). Diemers et al. (2015) observe that the appropriate understanding and application of legislation are business challenges for any entrant, and, in the case of fintechs, legislation strongly impacts their business. It was evident that, to comply with the legal aspects advocated by Brazilian regulatory bodies, it is necessary, first, that companies are able to understand the legislation in order to adapt to it and then comply with it.

However, although the legislation acts as a barrier to the entry of fintechs into the market, some of fintechs' entrepreneurs are in favor of the Central Bank's firm stance to prevent inadequate companies from entering the market, especially the malicious ones. These results are in line with the observation of Folwarski (2018), who states that the lack of action by regulatory agents can add risks to financial operations and legal uncertainty. Thus, the role of regulatory bodies is to understand the changes that have been occurring in the payment system and to regulate the market in order to protect customers and provide free competition (Folwarski, 2018).

Regarding the R\&D infrastructure (Van de Ven, 1993), this was not highlighted directly by the interviewees. Some of their R\&D activities are carried out together with major players, for example, in incubators or accelerators of large banks. There is no mention of public R\&D infrastructure or partnerships with other institutions, such as universities. This is a factor to be investigated in future research, as $\mathrm{R} \& \mathrm{D}$ environments can be created to support the fintechs, as happens with startups from other sectors (such as IT) in incubators, technology parks, accelerators, and other public or academic spaces that promote entrepreneurship and innovation in Brazil.

Other facilitating factors for the entry and development of fintechs is the existence of an unattended or poorly served market (Soriano, 2017). Fintechs work to provide solutions focused on meeting the needs of these unattended or under attended customers, also providing financial inclusion (Gabor \& Brooks, 2017). Iman (2018) states that the demand for financial services by consumers dissatisfied with the services received from traditional financial institutions is evident. Fintechs offer solutions based on convenience; the interviewees emphasized the ease, for customers, to make payments and transfers in just one click or without the need to carry a credit card, using only the mobile phone for this. On the other hand, adapting the technology to the public's wishes and monetizing the proposed solutions are mentioned as barriers. There is a wide market willing to consume new financial services, however, knowing the real needs of these customers and having a clear value proposition is essential (Lee, Ryu \& Lee, 2019).

The technology that enables the offering of these new services is understood as an essential condition for the very existence of fintechs. Using technology, they are able to achieve cost savings in transactions, offering value-added services (Shaikh, Hanafizadeh \& Karjaluoto, 2017). The implementation of innovative technologies can generate a competitive advantage vis-à-vis major players (Shaikh, Hanafizadeh \& Karjaluoto, 2017). On the other hand, the limited public ICT infrastructure becomes an evident technological barrier for the development of the fintech ecosystem (Gozman, Liebenau \& Mangan, 2018) in the Brazilian context.

The relationships with other actors in the fintech ecosystem in Brazil were highlighted both as facilitators and barriers to these companies. The partnership between fintechs was cited as a facilitator for the collaborative development of solutions, and adding technologies from partners is a differential. In addition, the strength of these partnerships, including the creation of a national association of fintechs (ABFintechs), demonstrates the importance of cooperation for this ecosystem. 
Considering the relationship with major players, fintechs consider big and traditional financial institutions in the domestic market as barriers to entry, even if, in some cases, they use the structure of these organizations (for example, credit card acquirers) as the basis for their transactions. They highlight the conflicts of interest with major players such as banks, financial institutions, and credit card companies. However, they point out that some large international players, such as venture capital funds and technology suppliers (such as international digital payment solutions) facilitate their operations. Understanding how these players act in the market and using their structures to develop and scale new solutions can transform a possible barrier in a business facilitator (Lee \& Shin, 2018).

Finally, a factor that emerged from the data, and which is not so present in the literature on fintechs, refers to the geographic location of these companies. The only fintech geographically distant from the Rio - São Paulo axis (the biggest financial center in Brazil) commented on the difficulty (barrier) of being outside the "center" of this ecosystem (Diemers et al., 2015; Lee \& Shin, 2018). The data suggest that geographical distance negativelly affects the acceptance and legitimacy of fintechs, which makes their access to resources more difficult.

The entry and development of fintechs in the markets has aroused the interest of some researchers, such as Klus et al (2019) and Clements (2018), who sought to analyze their interaction with traditional financial institutions and the need for their regulation, respectively. Analyzing these related studies, the results identified in this research are consistent with their previous findings, since the facilitators and barriers are present in the analyzed contexts.

Initially, the positioning of fintechs as companies that offer solutions at lower costs, with improved financial products and services, facilitating the access to credit, generates financial inclusion (Clements, 2018) to unattended costumers, with specific social conditions, through a differentiated service offering.

On the other hand, Klus et al. (2019) point out that innovation, as enabled by emergent technologies, challenges the business models of traditional players, such as banks and financial institutions, and demands that they adapt quickly to the needs of the digital age (which demands training and skilled human resources). At the same time, fintechs also face difficulties, such as meeting regulatory requirements and gaining the trust of potential customers (considering legal and regulatory factors).

These results indicate the need for joint and synergistic action between fintechs and banks (relationship with major players), which, in practice, is still rare, since there are still few partnership initiatives between them. Banks are particularly interested in benefiting from fast innovation, without necessarily getting involved in its development, while fintechs need resources (financial support; infrastructure to support R\&D processes) and know-how (non-financial support) to expand their operations in the highly regulated financial sector (Klus et al., 2019).

Finally, another aspect identified in related studies (Clements, 2018; Klus et al, 2019) and highlighted in this research concerning regulation (legal and regulatory factors), as fintechs impose new risks and challenges on regulators, such as the creation of laws that accurately capture possibilities generated by new technologies and keep pace with constantly evolving innovations. Therefore, it is essential that regulators balance the incentive to innovation and competition with effective risk management and supervision (Clements, 2018). 


\section{FINAL REMARKS}

This article aimed to identify facilitators and barriers faced by mobile payment fintechs for their entry and development in the Brazilian context. There was a convergence between the facilitators and barriers found in the literature and the empirical data observed in the Brazilian context. In addition, it was possible to identify particularities of the fintech ecosystem in the Brazilian context, according to the perception of fintechs' entrepreneurs.

Firstly, the existence of an unattended or poorly served market and the provision of solutions focused on satisfying the specific needs of customers act as a facilitator for the entry and development of fintechs, but adapting the technology to the public's wishes and monetizing the proposed solutions are mentioned as barriers. Technology is considered as a condition for the very existence of fintechs, reducing costs and adding value to potential customers (Shaikh et al., 2017). On the other hand, the scarcity of specialized human resources and a limited public ICT infrastructure becomes a barrier to the development of fintechs (Gozman, Liebenau \& Mangan, 2018).

The partnership between fintechs was cited as a facilitator for the development of solutionsand adding technologies from partners generates competitive advantages. The strength of these partnerships, including the creation of a fintech association, demonstrates the importance of collaboration to boost this ecosystem. The only startup geographically distant from the main financial center commented on the difficulty (barrier) of being an outsider in this context (Diemers et al., 2015; Lee \& Shin, 2018).

Regarding large players, fintechs consider national financial institutions as imposing barriers to their entry into the market, even if they use the structure of these organizations (for example credit card acquirers) as the basis for their transactions. The large international players are facilitators both for obtaining investments (venture capital funds) and technology (international digital payment solutions). Understanding how these players operate in the market and using their structures to develop and scale up new solutions can transform a possible barrier into a business facilitator (Lee \& Shin, 2018).

The results found regarding the barriers of existing regulations and possible legal gaps corroborate the literature (Folwarski, 2018), but, although the legislation is considered as a barrier to the entry of fintechs into the market, the work of the Central Bank to prevent opportunistic behavior in the market is valued by the fintechs. The research results contribute to the literature on fintechs, and to entrepreneurs or future entrepreneurs who wish to enter the Brazilian financial market, specifically in the payment sector. The results also provide subsidies for regulatory bodies and public policy developers.

However, although the methodological precautions were taken during this research, it is important to highlight some limitations. Although all the 34 mobile payment fintechs identified by the research were contacted, only nine agreed to participate in the study. Likewise, because it is a qualitative study (Case Study), and because the open data coding strategy was used, this implies the use of subjective criteria by the researchers, a fact that can interfere with the results presented. We sought to overcome this limitation by discussing the data later in the light of categories from the literature and comparing them with results from related studies. The general profile of the studied fintechs was also compared with the profile of Brazilian fintechs outlined in an ABfintech survey report (ABFINTECHS \& PwC 2018), verifying that they are similar, which increases the validity of the results presented here.

We suggest that future research analyze the role of ABFintechs as a representative of the interests of fintechs, specially in promoting their legitimacy to regulatory bodies and the Brazilian 
market in general, especially to investors. We also suggest to investigate issues related to conflicts of interest and the possible influence of major players on norms and rules established in the Brazilian financial system that can affect fintechs. Researching the insertion of fintechs in public R\&D environments and in academic environments, such as incubators or technology parks, is also relevant to expand the understanding of how to support these companies.

\section{REFERENCES}

ABFINTECHS \& PwC. Pesquisa Fintech Deep Dive 2018. Available at: https://www.pwc.com.br/ pt/setores-de-atividade/financeiro/2018/pub-fdd-18.pdf. Accessed: 14 Oct 2019.

A revolução dos pagamentos: da moeda ao smartphone. 2018. Available at: <https://bit.ly/2QmdYeA $>$. Accessed 24 Feb. 2019.

Arner, D. W.; Zetzsche, D. A.; Buckley, R. P. \& Barberis, J. N. (2019). The Identity Challenge in Finance: From Analogue Identity to Digitized Identification to Digital KYC Utilities. European Business Organization Law Review, 20(1), 55-80.

Bruton, G., Ahlstrom, D., \& Li, H. (2010). Institutional theory and entrepreneurship: where are we now and where do we need to move in the future? Entrepreneurship theory and practice, 34(3), 421-440.

Conheça as principais tendências do mercado de fintechs em 2017. (2017) Conexão Fintech. Available at <http://conexaofintech.com.br/fintech/conheca-as-principais-tendencias-do-mercado-de-fintechsem-2017>. Accessed 14 Jun. 2017.

Clements, R. (2018) Regulating Fintech in Canada and the United States: Comparison, Challenges and Opportunities. University of Calgary, School of Public Policy Research Series, 2019. Available at SSRN: https://ssrn.com/abstract=3304759

Dahlberg, T., Guo, J. \& Ondrus, J. (2015). A critical review of mobile payment research, Electronic Commerce Research and Applications, 14(5), 265-284.

Dallagnol, A. \& Verschoore Filho, J. (2018). As Abordagens Estratégicas Adotadas pelas Fintechs Brasileiras para Competir na Indústria de Meios Eletrônicos de Pagamentos. In Anais do XLII ENANPAD, Curitiba, 1-17.

Diemers, D., et al. (2015). Developing a FinTech ecosystem in the GCC. Strategy\&. Retrieved from https:/www.strategyand.pwc.com/media/file/Developing-a-FinTech-ecosystem-in-the-GCC. pdf, accessed June 24, 2019.

Du, K. (2018). Complacency, capabilities, and institutional pressure: understanding financial institutions' participation in the nascent mobile payments ecosystem. Electronic Markets, 28(3), 307-319.

Eisenhardt, K. M. (1989). Building theories from case study research. Academy of Management Review, 14(4), 532-550.

Fenwick, M., Kaal, W. \& Vermeulen, E. (2018). Regulation Tomorrow: Strategies for Regulating New Technologies. In: Transnational Commercial and Consumer Law. [s.l.] 153-174.

Folwarski, M. (2018). The impact of selected regulations on the development of payments systems in Poland. Marketing and Management Innovation, 3.

Gabor, D.; Brooks, S. (2017). The digital revolution in financial inclusion: international development in the fintech era. New Political Economy, 22(4), 423-436. 
Gnyawali, D., \& Fogel, D. (1994). Environments for entrepreneurship development: key dimensions and research implications. Entrepreneurship: theory and practice, 18(4), 43-63.

Gomber, P. et al. (2018). On the fintech revolution: interpreting the forces of innovation, disruption, and transformation in financial services. Journal of Management Information Systems, 35(1), 220-265.

Gozman, D., Liebenau, J. \& Mangan, J. (2018). The innovation mechanisms of fintech startups: insights from SWIFT's innotribe competition. Journal of Management Information Systems, 35(1), $145-179$.

Iman, N. (2018). Is mobile payment still relevant in the fintech era? Electronic Commerce Research and Applications, 30, 72-82, 2018.

Klus, M. F.; Lohwasser, T. S.; Holotiuk, F. \& Moormann, J. (2019) Strategic Alliances between Banks and Fintechs for Digital Innovation: Motives to Collaborate and Types of Interaction. The Journal of Entrepreneurial Finance, 21 (1), 1-23.

Lee, C., Lee, K., \& Pennings, J. (2001). Internal capabilities, external networks, and performance: a study on technology-based ventures. Strategic management journal, 22(6-7), 615-640.

Lee, I. \& Shin, Y. (2018). Fintech: Ecosystem, business models, investment decisions, and challenges. Business Horizons, 61(1), 35-46.

Lee, J., Ryu, M. \& Lee, D. (2019). A study on the reciprocal relationship between user perception and retailer perception on platform-based mobile payment service. Journal of Retailing and Consumer Services, 48, 7-15.

Leong, C. et al. (2017). Nurturing a FinTech ecosystem: The case of a youth microloan startup in China. International Journal of Information Management, 37(2), 92-97.

Miranda, J., Júnior, S., Denner, C., \& Dias, A. (2016). A influência das variáveis ambientais e organizacionais no desempenho de startups. Revista de Empreendedorismo e Gestão de Pequenas Empresas, 5(1).

Moon, W. A (2017) Coinless Society as a Bridge to a Cashless Society: A Korean Experiment. In: Cash in East Asia. Springer, 2017, 101-115.

Murshudli, F. \& Loguinov, B. (2019) Digitalization challenges to global banking industry. Economic and Social Development: Book of Proceedings, 786-794.

Prado, J. (2016) O que é Fintech? Conexão Fintech, 14 dez. 2016. Available at <https://bit.ly/2Wc6Ffx>. Accessed 14 Jun. 2017.

Reynolds, P. (1991). Sociology and entrepreneurship: Concepts and contributions. Entrepreneurship theory and practice, 16(2), 47-70.

Romānova, I. \& Kudinska, M. (2016). Banking and Fintech: a challenge or opportunity? In: Contemporary Issues in Finance: Current Challenges from Across Europe. Emerald, 21-35.

Saldaña, J. (2009). The coding manual for qualitative researchers. Los Angeles: Sage.

Shaikh, A. A., Hanafizadeh, P. \& Karjaluoto, H. (2017). Mobile banking and payment system: A conceptual standpoint. International Journal of E-Business Research, 13(2), 14-27.

Shane, S., \& Venkataraman, S. (2000). The promise of entrepreneurship as a field of research. Academy of management review, 25(1), 217-226.

Steininger, D. (2019). Linking information systems and entrepreneurship: A review and agenda for IT-associated and digital entrepreneurship research. Information Systems Journal, 29(2), 363-407. 
BBR

18

44

Sussan, F. \& Acs, Z. (2017). The digital entrepreneurial ecosystem. In: Small Business Economics, 49(1), 55-73.

Van de Ven, H. (1993). The development of an infrastructure for entrepreneurship. Journal of Business venturing, 8(3), 211-230.

Yin, R. K. (2015). Estudo de Caso: Planejamento e métodos. Bookman.

\section{AUTHOR'S CONTRIBUTION}

The first author was responsible for collecting data and conducting the research as a whole; the second author was the research supervisor and contributed to the writing of the article and part of the literature review; the third author contributed to the literature review.

\section{ACKNOWLEDGEMENT}

The authors thank CAPES and CNPq for the financial support of this research (Ph.D scholarship of Gabriel Braido and Productivity Grant of Amarolinda Klein, respectively).

\section{CONFLICTS OF INTEREST}

The authors declare that there is no conflict of interest in the publication of this article. 